\title{
Automation of The Palembang Semage Fabric Yarn Spinner
}

\author{
Eka Susanti ${ }^{1, *}$ Ica Admirani $^{1}$ Romi Wilza $^{1}$ Irawan Hadi $^{1}$ Sholihin Sholihin ${ }^{1}$ \\ ${ }^{1}$ State Polytechnic of Sriwijaya \\ *Corresponding author. Email: ekasusanti@polsri.ac.id
}

\begin{abstract}
Songket weaving craft of Palembang City has been the center of the easy ikat weaving craft since ancient times and has become the hallmark of the city of Palembang. Currently the production process used by the songket weaving craft is still very simple, most of the work process in making this woven fabric is done manually. This causes the production process to take a relatively long time compared to the manufacture of fabrics in general. The yarn spinning device is modified in such a way that the yarn spinner can work with the help of electronic components. The yarn spinner is given a DC motor which has previously been programmed using the L298N Motor Driver so that it can rotate as needed and is connected to the Node MCU ESP8266 module so that it can be connected to an Android Smartphone which is used as a remote control to run the yarn spinning device. The ESP8266 Node MCU functions as a command provider for each component, the Gearbox DC Motor functions as the main driver for the coils, the L298N Motor Driver functions as a DC Motor controller, and the MG966R Servo Motor functions as a thread guide to the left and right so that the results of the thread roll look neat. The results of testing how many spools of yarn are in a fast IoT state in a period of 5-60 minutes at a time of 60 minutes get very fast results compared to manual.
\end{abstract}

Keywords: Artificial Intelligent, Arduino UNO, Embedded System, Modul ESP 826

\section{INTRODUCTION}

Songket Weaving The city of Palembang has been the center of easy ikat weaving since ancient times and has become a hallmark of the city of Palembang. Currently the production process used by the songket weaving craft is still very simple, most of the work process in making this woven fabric is done manually. This causes the production process to take a relatively long time compared to the manufacture of fabrics in general. A series of work processes in the manufacture of woven fabrics consists of 2 types of processes, namely the process of winding yarn and the process of making cloth. In the manufacture of this thread winding consists of the process of winding the thread and arranging the thread. While the fabric making process consists of theprocessreek (arranging the threads in the field), giving motifs/designing images, binding motifs, colet(giving color combinations), dyeing, releasing ropes, unraveling threads to be used as bait, spinning weft on pallets and lastly. is the weaving process. If the sum of the entire work process, it takes as many as 14 work processes to make woven fabrics. This numberof series of processes causes the process of making this woven cloth to take a long time.

The lack of facilities for supporting the production process in Palembang Songket Weaving is in the process of winding yarn. Based on observations, it is known that the thread roller used by the people of Palembang is still very simple and takes a long time. Based on this, the problem in this design is whether the existing design of the yarn winder can minimize the production process time effectively and efficiently? How is the winding machine that can minimize production time to be effective and efficient? The design of this tool focuses on the effectiveness and efficiency of yarn winding time. Where this thread winder must be able to meet the needs and desires of workers. Through the development of this tool system, it is hoped that the community can be fast in terms of winding yarn. Where this system will make it easier for people to roll the thread. So based on the tool system thinking above. 


\section{DESIGN SYSTEM}

In the design there are three underlying elements, namely functional, aesthetic, and economic. Good design means having a good quality of function, depending on the goals and general design philosophy, that the goals differ according to needs and interests, and that design efforts are oriented to the results achieved, implemented and carried out as optimally as possible.

This research is a research that aims to create software that can be used as a controller for the songket woven thread winder which is expected to minimize the time used when rolling the thread if it is done manually.

In making this software use the Arduino IDE and software. Android Studio The Android Studio software is used to create applications that function as on/off controllers and the speed of dc motors and the Arduino IDE software is used to create programs to connect android applications to NodeMCU via wifi to drive dc motors and servos.

Previously made block diagrams, that function to determine how the entire programming circuit will work on the software used.

Electronic design is about all stages related to all series of tools, such as layout circuits and component installation. Mechanical design is the process of completing a tool which includes the manufacture of mechanical tools to optimize the appearance of the tool made. The process of designing a thread winder using an IoT-based DC motor begins with determining the initialization of the components to be used, then proceeds with tool design, after that, installs components, and after that makes a simulation of the tool that has been made.

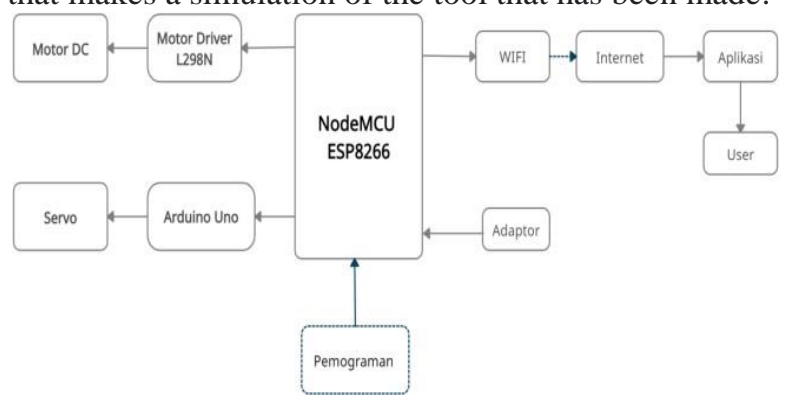

Figure 1 Block Diagram System

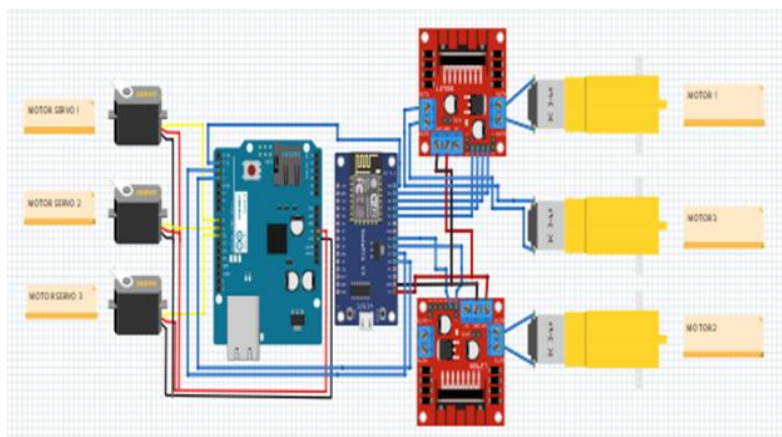

Figure 2 Desain Using Automation of the Palembang Semage Fabric Yarn Spinner

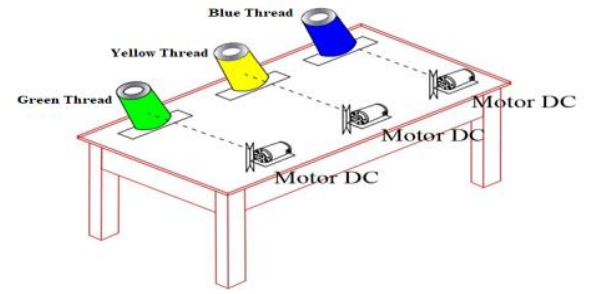

Figure 3 Tool Disign for Mechanic

\section{CURRENT RESULT}

In determining the results of the test, the researcher will use uses the Node MCU ESP 8266 which is in charge of giving orders, processing all inputs and regulating all outputs., Gearbox DC Motor serves as the main driver for the coils, L298N Motor Driver functions as a DC Motor controller, and Servo Motor MG966R which functions as a thread guide to the coil. left and right so that the results of the thread roll look neat.

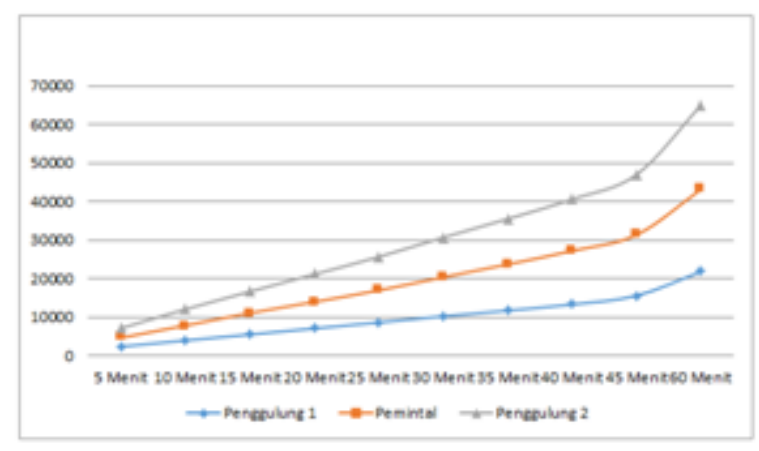

Figure 4 Graph for Fast Yarn Roll

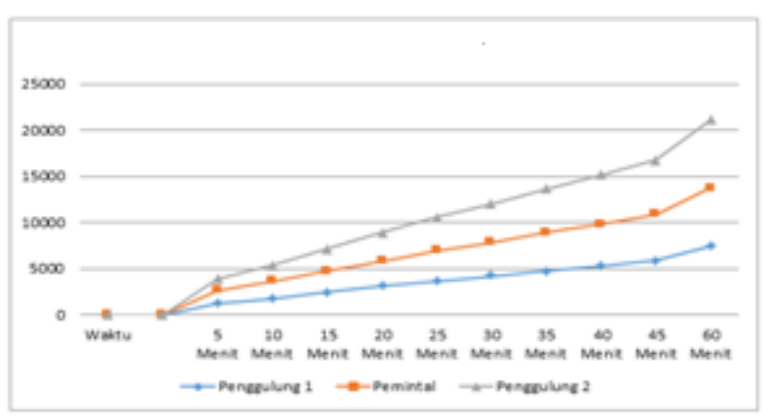

Figure 5 Medium Yarn Roll

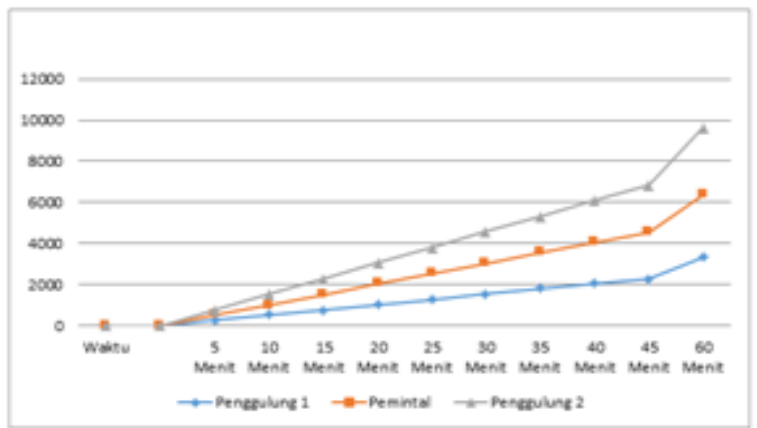

Figure 6 Manual Yarn Roll 


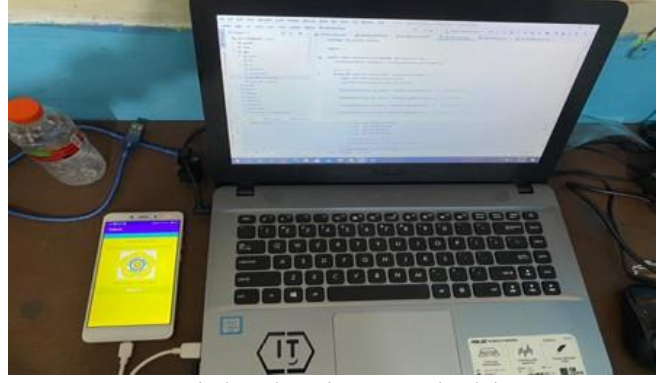

Figure 7 Program injection into Android

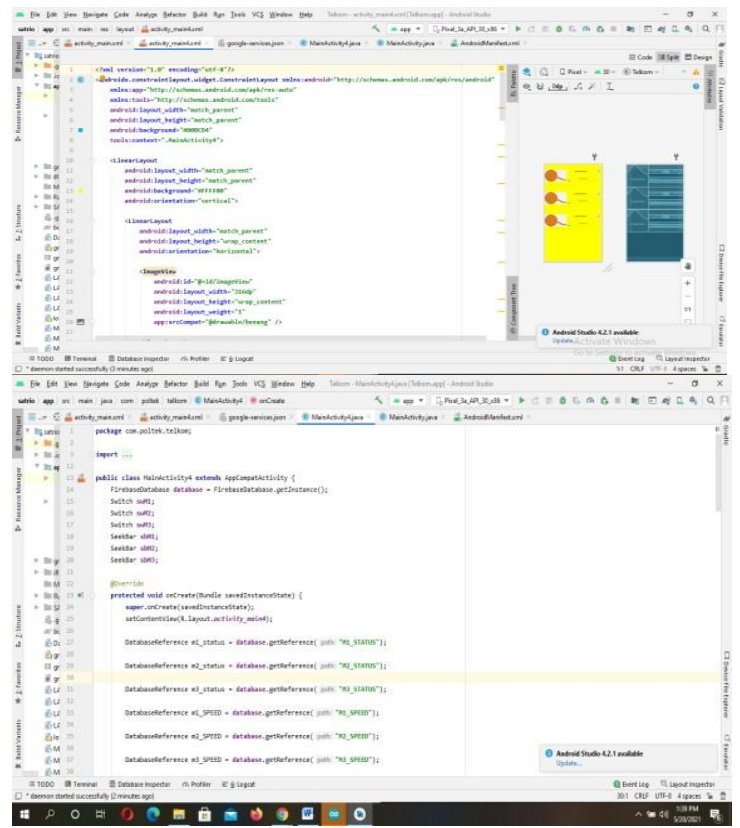

Figure 8 Sketch Layout Controller and Sketch Switch and Speed

Table 1 Based on the tests that have been carried out, the testdata obtained are as follows

\begin{tabular}{|c|c|c|c|l|}
\hline \multicolumn{2}{|c|}{$\begin{array}{c}\text { Motor Condition Onthe } \\
\text { Android Application }\end{array}$} & Speed & Description \\
\hline M1 & M2 & M3 & & \\
\hline OFF & OFF & OFF & 0 & $\begin{array}{l}\text { three DC } \\
\text { motors on } \\
\text { the } \\
\text { mechanical } \\
\text { rollers do } \\
\text { not } \\
\text { move. }\end{array}$ \\
\hline ON & OFF & OFF & 100 & $\begin{array}{l}\text { The first DC } \\
\text { motor on the } \\
\text { mechanical } \\
\text { roller is } \\
\text { moving, } \\
\text { while the } \\
\text { second } \\
\text { and third do } \\
\text { not move }\end{array}$ \\
\hline OFF & ON & OFF & 100 & $\begin{array}{l}\text { The second } \\
\text { DC motor on }\end{array}$ \\
\hline
\end{tabular}

\begin{tabular}{|c|c|c|c|c|}
\hline & & & & $\begin{array}{l}\text { the mechanic } \\
\text { The roller is } \\
\text { moving, } \\
\text { while the } \\
\text { first andthird } \\
\text { do not move }\end{array}$ \\
\hline $\mathrm{OFF}$ & OFF & $\mathrm{ON}$ & 100 & $\begin{array}{l}\text { The third DC } \\
\text { motor on the } \\
\text { mechanic } \\
\text { Tool the } \\
\text { rollers move, } \\
\text { while the } \\
\text { first and } \\
\text { second } \\
\text { immovable }\end{array}$ \\
\hline ON & ON & $\mathrm{ON}$ & 100 & $\begin{array}{l}\text { Third Motor } \\
\text { DC on } \\
\text { mechanical } \\
\text { equipment } \\
\text { moving at a } \\
\text { speed spindle } \\
100 \text {. }\end{array}$ \\
\hline $\mathrm{ON}$ & ON & $\mathrm{ON}$ & 50 & $\begin{array}{l}\text { Third Motor } \\
\text { DC on } \\
\text { mechanical } \\
\text { spindle tool } \\
\text { moving at a } \\
\text { speed } \\
\text { reduced } \\
\text { to } 50 .\end{array}$ \\
\hline
\end{tabular}

\section{CONCLUSION}

The results of testing how many spools of yarn are in a fast IoT state in a period of 5-60 minutes at a time of 60 minutes get very fast results compared to manual. The results of IoT in slow conditions, IoT slowing down caused by network connection factors that have an impact on the tool, the result is that at 60 minutes, IoT is slightly slower than fast IoT. The results of the spools are done manually using mechanical power to roll. The results of the spools in 60 minutes are only 3,000 spools, this proves that IoT is able to work to roll threads very quickly compared to rolling still using manual power.

\section{AUTHORS' CONTRIBUTIONS}

"Eka susanti' creating is making research data collection, with the testing how many spools of yarn are in a fast iot".

\section{ACKNOWLEDGMENTS}

" In writing this paper, the researcher has conducted several sample trials with reference to references as reference material, to improve this paper, the researcher also thanks the previous authors, and the researcher also 
apologizes if there are different writing words. Thank you once again we the researchers say"

\section{REFERENCES}

[1]. Craig, J.J. 2005. Introduction to Robotics. Pearson Prentice Hall. Upper Saddle River, New Jersey

[2]. Eka susanti, Rosita febriani, Sholihin,Emilia hesti, 2018, The design of hand gesture robot software based on wireless technology, IEEE conferences ICOIACT 2018, Indonesia, p.p 401 - 406.

[3]. Harmalia, Dita. 2015. Pengaturan otomatis gerak kamera pada robot pendeksi logam di air tawar berbasis mikrokontroler Atmega 16., Other thesis, Politeknik Negeri Sriwijaya.

[4]. Pitowarno, Endra. 2006. Robotika Desain, Kontrol, dan Kecerdasan Buatan. Yogyakarta: Andi
[5]. Sholihin, Eka Susanti, "Humanoid Robot Control System Balance Dance Indonesia and Reader Filters Using Complementary Angle Value", E3S Web of Conferences 31, 2018.

[6]. Thangavel, D. 2014. Performance Evaluation of $M Q T T$ and CoAP via a Common Middleware, Singapore.

[7]. Waluyo, Yoyo .2015. Robot Boat pengintai berbasis arduino dengan L293D. Other thesis, Politeknik Negeri Sriwijaya.

[8]. Maulana., "Humanoid Robot and Artificial Intelligence, Bandung, 2013, Departement of Computer,STIMIK-AKI, Semarang, 2013. 